\title{
Construction and Testing of an Experimental Sprinkler/Groundwater Treatment System for Proposed Use by the Village of Utica, Nebraska
}

prepared by

Environmental Research Division

Argonne National Laboratory
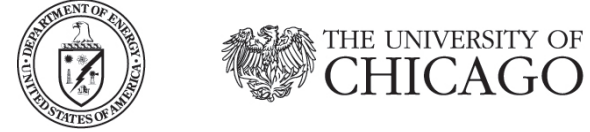

Argonne National Laboratory is managed by The University of Chicago for the U.S. Department of Energy

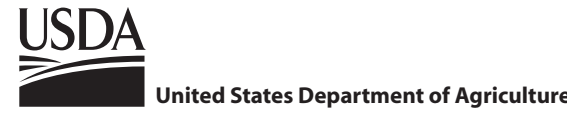

Work sponsored by Commodity Credit Corporation United States Department of Agriculture 


\begin{abstract}
About Argonne National Laboratory
Argonne is managed by The University of Chicago for the U.S. Department of Energy under contract W-31-109-Eng-38. The Laboratory's main facility is outside Chicago, at 9700 South Cass Avenue, Argonne, Illinois 60439. For information about Argonne and its pioneering science and technology programs, see www.anl.gov.
\end{abstract}

\title{
Availability of This Report
}

This report is available, at no cost, at http://www.osti.gov/bridge. It is also available on paper to U.S. Department of Energy and its contractors, for a processing fee, from:

U.S. Department of Energy

Office of Scientific and Technical Information

P.O. Box 62

Oak Ridge, TN 37831-0062

phone (865) 576-8401

fax (865) 576-5728

reports@adonis.osti.gov

\section{Disclaimer}

This report was prepared as an account of work sponsored by an agency of the United States Government. Reference herein to any specific commercial product, process, or service by trade name, trademark, manufacturer, or otherwise, does not necessarily constitute or imply its endorsement, recommendation, or favoring by the United States Government or any agency thereof.

The views and opinions of document authors expressed herein do not necessarily state or reflect those of the United States Government or any agency thereof, Argonne National Laboratory, or The University of Chicago. 


\section{Construction and Testing of an Experimental Sprinkler/Groundwater Treatment System for Proposed Use by the Village of Utica, Nebraska}

by

Applied Geosciences and Environmental Management Section

Environmental Research Division, Argonne National Laboratory

January 2000 


\section{Construction and Testing of an Experimental Sprinkler / Groundwater Treatment System for Proposed Use by the Village of Utica, Nebraska}

\section{Background}

The Village of Utica takes pride in the municipal baseball fields located in the northwest portion of the village (See Figure 1). These fields are carefully maintained by the Village, have recently had the addition of lights to permit night play, and are frequently used by additional nearby communities for local tournaments. Prior to 1995 the playing fields were regularly watered, from the town's municipal supply system, throughout the summer months. The Village discontinued watering in fall of 1995, due to the installation of a water treatment plant for the removal of nuisance concentrations of iron and manganese from the municipal water supply. Since that time, the Village has sought an alternative means for irrigating the fields.

Groundwater used by the town for the municipal supply is obtained exclusively from a deep, confined sand aquifer that is separated by a thick, relatively impermeable clay unit from a shallower, unconfined sand aquifer (Argonne 1993a, 1993b). Testing of the groundwater from these units has indicated that a carbon tetrachloride plume is present within the shallow aquifer (See Figure 1) only, extending from northwest to southeast beneath the center of the town. Nitrate contamination has also been identified in the shallow aquifer in the vicinity of the town, however, the occurence of nitrate concentrations $>10 \mathrm{mg} / \mathrm{L}$ is sporadic both areally and with depth (Argonne 2000). Groundwater from this aquifer is not currently being used for any purpose within the village.

Pilot groundwater treatment studies being conducted by Argonne on behalf of the Commodity Credit Corporation of the U.S. Department of Agriculture (CCC/USDA) have demonstrated that spray discharge using conventional agricultural irrigation equipment (center-pivot spray heads and discharge nozzles) can be used to effectively remove carbon tetrachloride from the shallow aquifer groundwater at Utica, under appropriate weather and spray discharge conditions (Argonne 2000). In an effort to assist the Village of Utica, CCC/USDA commissioned Argonne to develop a small-scale, mobile spray-discharge system (i.e., a 'sprinkler') based on these studies, that could be used by the Village to irrigate the playing fields with treated groundwater from the contaminated upper aquifer. Groundwater could be supplied to the sprinkler from an existing well located near the margin of the playing fields (see Figure 1), that was previously installed to conduct aquifer pumping tests in the shallow sand.

\section{Sprinkler Design}

To meet this request, Argonne constructed a light-weight, portable sprinkler (see Figure

2 ) that can be equipped with up to 6 spray discharge heads, mounted on a $24 \mathrm{ft}$ long horizontal boom. The boom arms can be folded to simplify transport of the unit. The 
sprinkler was designed for use with a commercial hydraulically powered drive unit (Kifco Model B130 Water-Reel ${ }^{\mathrm{TM}}$; see Figure 3) owned by the Village that can be used to automatically tow the sprinkler across the playing fields. The amount of water supplied by the sprinkler to any point on the ground is determined by (1) the selection of spray nozzles mounted on the boom arm, (2) the operating pressure of the system, and (3) the travel rate of the drive unit.

\section{Sprinkler Testing}

\subsection{Test Conditions}

Field testing of the sprinkler was performed (1) to verify that carbon tetrachloride levels in the sprayed groundwater reaching the ground surface can be reduced to a target concentration below $5 \mu \mathrm{g} / \mathrm{L}$ (the U.S.EPA promulgated Maximum Contaminant Level [MCL] for carbon tetrachloride in drinking water) under reasonable operating conditions, and (2) to obtain basic data on the discharge characteristics of the sprinkler, for use by the Village in evaluating their watering needs for the fields.

Testing of the sprinkler and hydraulic drive unit was performed at the purpose-built groundwater treatment research facility (see Figure 1) constructed by Argonne near the southeast edge of Utica (Argonne 1998). Contaminated groundwater from the shallow aquifer is supplied to the research site from an extraction well located in the approximate center of the mapped carbon tetrachloride plume, near the zone of maximum measured groundwater concentrations.

The experiments were conducted by towing the sprinkler (using the Water-Reel ${ }^{\mathrm{TM}}$ drive unit) past a line of stationary rain gauges oriented perpendicular to the direction of sprinkler travel and 30in above ground (see Figure 4). The gauges were placed ahead of the sprinkler, beyond the limits of the spray outfall, at the start of each test. Towing was continued past the line of rain gauges, until they were again beyond the limits of spray outfall behind the sprinkler. Precipitation levels at each gauge were then recorded, and samples of the captured spray from each gauge were collected for VOC analyses. For four of the test tuns (see Table 1) a rain gauge was also placed on the moving sprinkler, located within the coarsest portion of the spray pattern. Run 070 (see Table 1) was performed to obtain precipitation data only.

The water samples were analyzed using both headspace GC/ECD and purge-and-trap GC/MS methodologies. The headspace method was employed because it requires only a small sample volume, and therefore permitted analyses from the rain gauges near the outer edges of the spray pattern. Samples for purge-and-trap analysis were collected for comparison to the headspace data from all gauges that received sufficient spray, and from the groundwater supply hydrant at the beginning and end of each test run. All analyses were performed by the Applied Geosciences and Environmental Management (AGEM) Analytical Laboratory in the Environmental Research Division at Argonne National Laboratory, Argonne, Illinois. 
Spray head, operating pressure, and travel speed configurations were selected for the experiments based on the results of Argonne's previous spray-irrigation treatment studies at the Utica site (Argonne 2000). These parameters were also chosen to be suitable for routine operation of the sprinkler and drive system in conjunction with the former pumptest well near the edge of the playing fields. The Model B130 Water-Reel ${ }^{\mathrm{TM}}$ is rated for continuous operation at water inlet pressures of up to $100 \mathrm{psi}$. The conditions of each experimental sprinkler run are summarized in Table 1.

\subsection{Groundwater Treatment Results}

VOC analysis results for the sprayed groundwater samples collected during each experimental sprinkler run, and for samples of the untreated groundwater collected directly from the pipeline supply hydrant at the beginning and end of each experiment, are presented in Tables $2 \mathrm{a}$ (purge-and-trap method) and $2 \mathrm{~b}$ (headspace method).

Carbon tetrachloride concentrations in the untreated groundwater varied from $95 \mu \mathrm{g} / \mathrm{L}$ to $278 \mu \mathrm{g} / \mathrm{L}$ during the course of the sprinkler testing, and showed no clear trend of variation over time. Similar variability in the carbon tetrachloride concentrations in groundwater produced from the test well were observed during the previous pilot program experiments conducted at the site (Argonne 2000), and are believed to reflect natural inhomogeneities in the small-scale distribution of the contaminant within the upper aquifer.

Tables $2 \mathrm{a}$ and $2 \mathrm{~b}$ indicate that (with one exception only) the observed concentrations of carbon tetrachloride in the spray discharged to the ground were below $5 \mu \mathrm{g} / \mathrm{L}$ for all of the experimental conditions tested. Only one sample result, from Run $063(5.2 \mu \mathrm{g} / \mathrm{L}$; see Table 2b) slightly exceeded the target clean-up value. The experimental results indicate an efficiency of $>95 \%$ for the removal of carbon tetrachloride from the untreated groundwater, using the sprinkler within the range of operating conditions tested. The results demonstrate that the sprinkler and hydraulic drive system could be used by the Village, under routine operating conditions, to provide irrigation water that would be free of any carbon tetrachloride contamination above the MCL.

\subsection{Sprinkler Discharge Results}

Prior to 1995 , Utica used the Water-Reel ${ }^{\mathrm{TM}}$ drive unit in combination with a standard single-head impact sprinkler to irrigate the playing fields. This type of sprinkler provides a wide radius of coverage (typically $35-50 \mathrm{ft}$ ), but yields a relatively low application rate (i.e., the amount of water, measured in inches, supplied to the ground per passage of the sprinkler; typically $<1$ inch for the former Utica system). Discussions with representatives from the Village indicated that they would normally try to achieve an application of 0.5 to 0.75 inch per watering of the playing fields, which required that the sprinkler operate almost continuously throughout the summer months. Argonne testing has shown that this type of sprinkler cannot be used effectively for the removal of carbon tetrachloride from the groundwater at Utica. 
Groundwater application data obtained from the series of tests performed with the experimental Utica sprinkler are summarized in Table 3, Table 4, and Figure 5.

The operating configurations tested yielded a narrower radius of coverage, but generally higher application rates (for a given total flow rate and sprinkler towing speed) than the

previous impact sprinkler. The initial tests demonstrated that the experimental sprinkler could be used to meet the watering goals of the village with less frequent and quicker applications, however, the sprinkler and drive unit may have to be repositioned more often, when they are used, to provide uniform coverage of the playing fields.

\section{Summary and Recommendations}

The testing described above demonstrates that the experimental sprinkler designed by Argonne could be successfully, and safely, used by the Village of Utica for irrigation of the town's playing fields, using contaminated (by carbon tetrachloride) groundwater from the shallow aquifer beneath the town. Routine operation of the sprinkler within the range of parameters identified by the testing program would effectively reduce carbon tetrachloride concentrations in the discharged spray reaching the ground to levels below the MCL $(5 \mu \mathrm{g} / 1)$.

CCC/USDA and Argonne propose to test use of the experimental sprinkler by the Village of Utica during the next (Summer 2001) growing season, under Argonne supervision. Water will be supplied from the well to the sprinkler drive unit using a temporary, flexible (high-pressure hose) connection. Argonne will provide training to Village staff in the setup and use of the sprinkler, and will conduct periodic monitoring (proposed biweekly, initially) of the watering operations and sampling and analysis of the spray discharge from the unit, to ensure that the specified groundwater cleanup performance of the sprinkler system (to carbon tetrachloride values $<5 \mu \mathrm{g} / \mathrm{L}$ ) is maintained. If testing of the sprinkler in this manner proves successful during 2001, CCC/USDA will seek to permanently transfer ownership and operation responsibilities for the sprinkler to the Utica Village Board. 


\section{References}

Argonne, 1993a, Final Phase I Report and Phase II Work Plan: Extended Site Characterization, Utica, Nebraska, report prepared for the Commodity Credit Corporation, U.S. Department of Agriculture, by Argonne National Laboratory, Argonne, Illinois, June.

Argonne, 1993b, Final Repor: Expedited Site Characterization, Utica, Nebraska, report prepared for the Commodity Credit Corporation, U.S. Department of Agriculture, by Argonne National Laboratory, Argonne, Illinois, December.

Argonne, 1998, Final Work Plan: Agricultural/Environmental Enhancement Pilot Program, Spray Irrigation Testing, Utica, Nebraska, report prepared for the Commodity Credit Corporation, U.S. Department of Agriculture, by Argonne National Laboratory, Argonne, Illinois, November.

Argonne, 2000, Final Report: Stage I Investigations of the Agricultural/Environmental Enhancement Pilot Program, Utica, Nebraska, report prepared for the Commodity Credit Corporation, U.S. Department of Agriculture, by Argonne National Laboratory, Argonne, Illinois, January. 


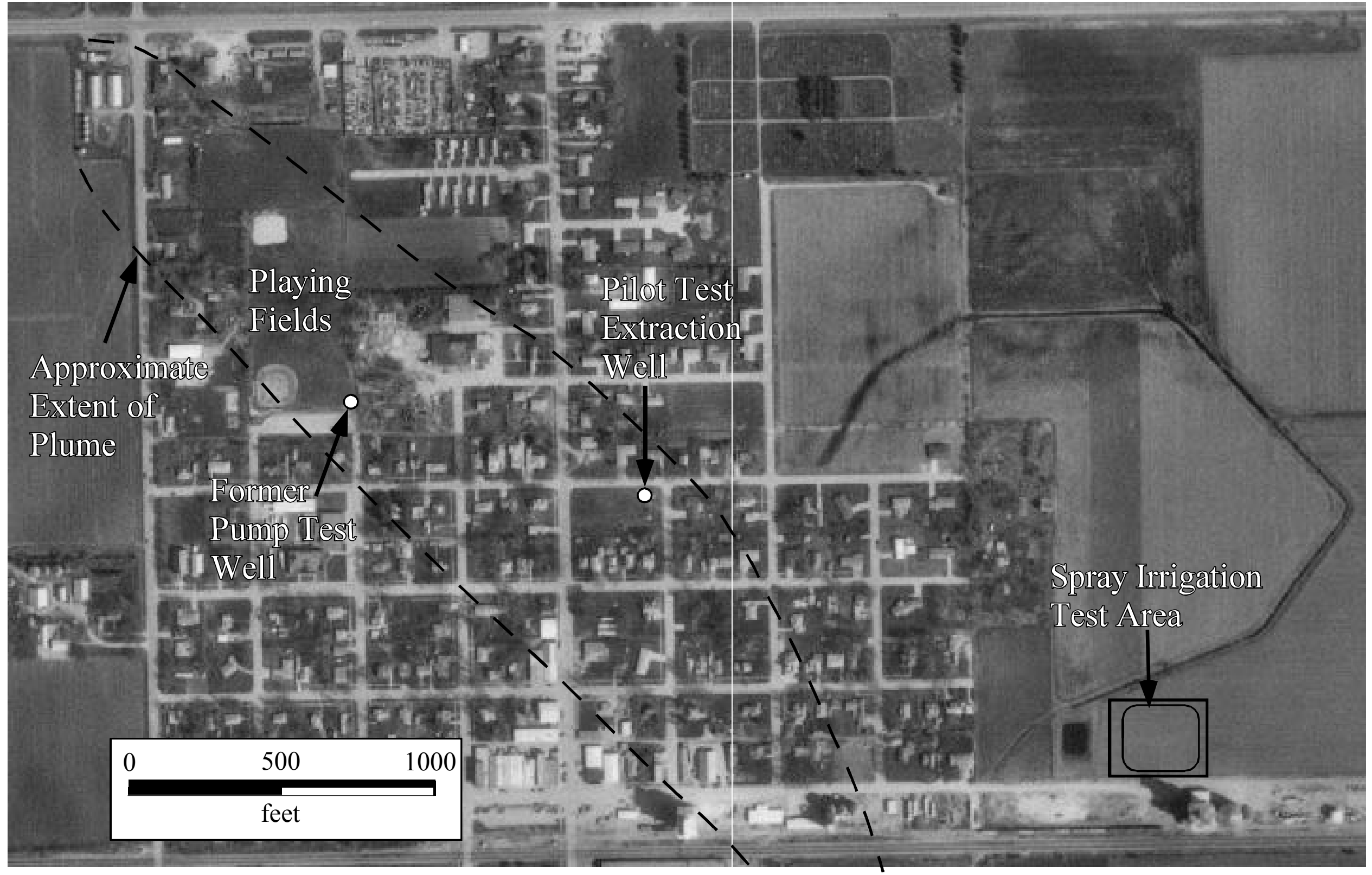




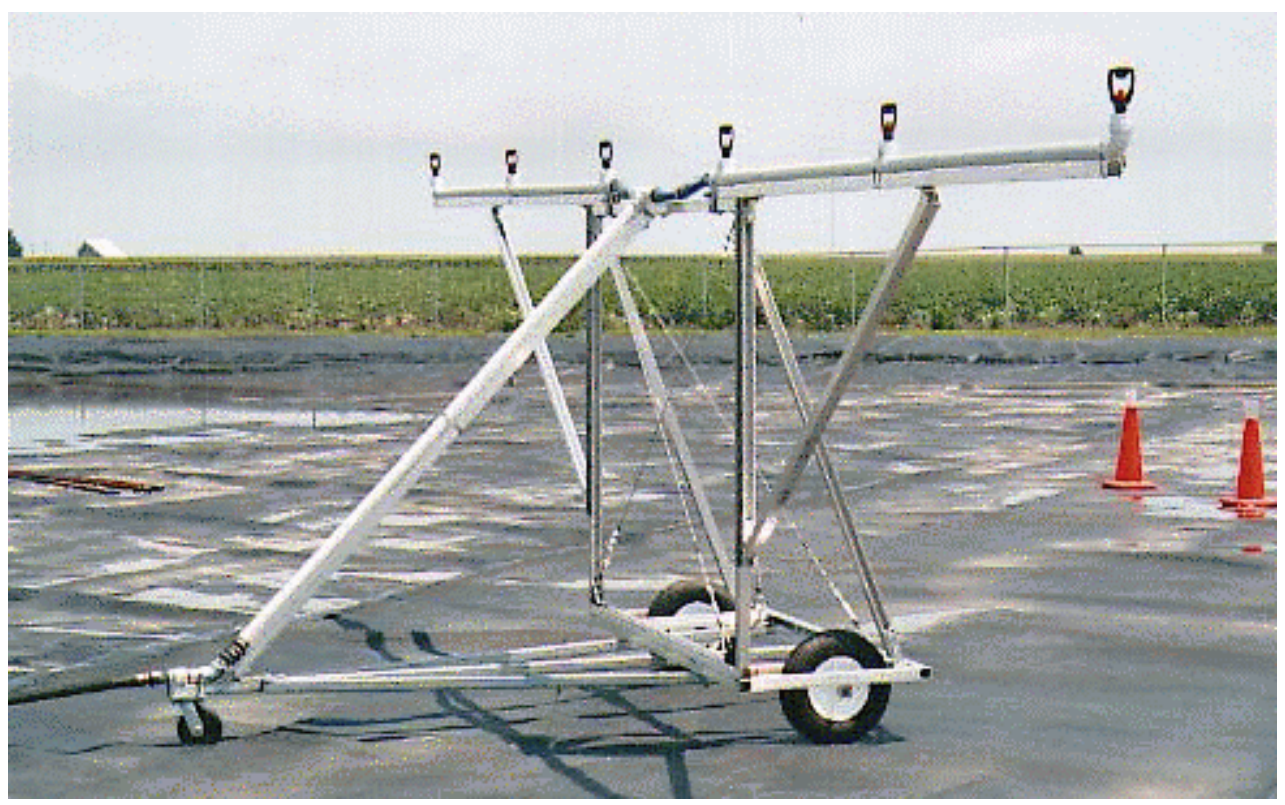

Figure 2 - Experimental Sprinkler Constructed by Argonne.

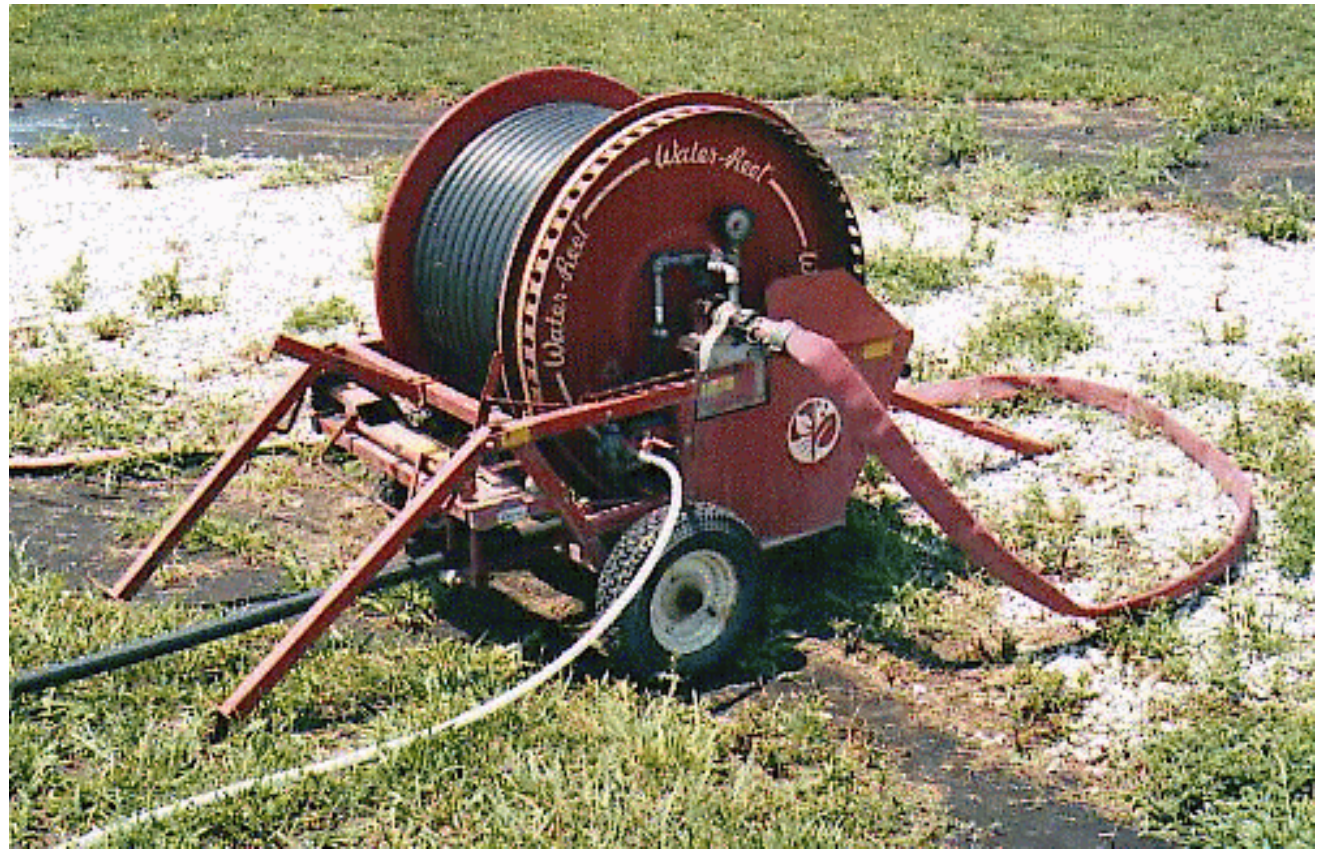

Figure 3 - Water-Reel ${ }^{\mathrm{TM}}$ Hydraulic Sprinkler Drive Unit Owned by the Village of Utica. 


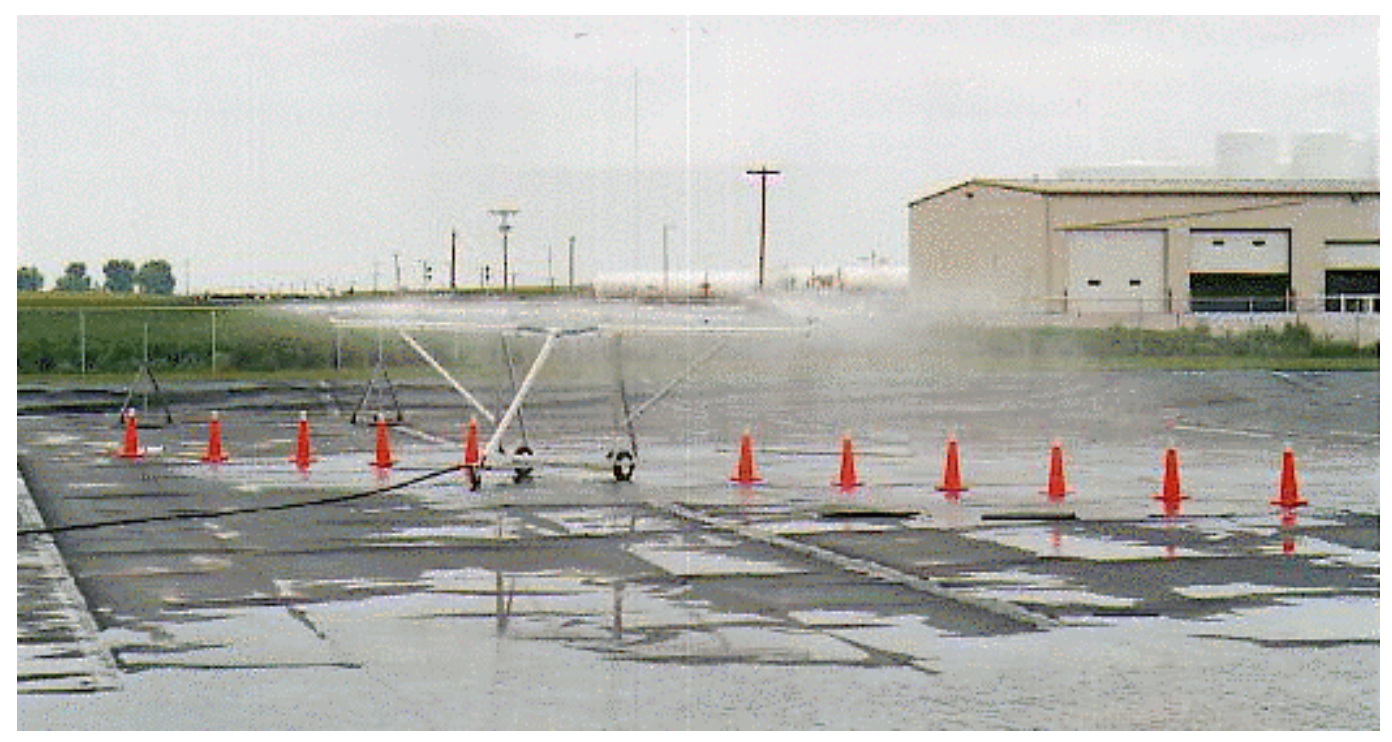

Figure 4 - Experimental Set-Up Used to Test the Performance of the Sprinkler.



Figure 5 - Sprinkler Discharge Results, Application Depths in Inches of Water. 
Table 1

Summary of Village Sprinkler Experiments

\begin{tabular}{|c|c|c|c|c|c|c|c|c|c|c|c|}
\hline \multirow[b]{2}{*}{ Run No. } & \multirow{2}{*}{$\begin{array}{c}\text { Reel Inlet } \\
\text { Pressure } \\
\text { (psi) } \\
\end{array}$} & \multicolumn{3}{|c|}{ Spray Nozzle Sizes* } & \multirow{2}{*}{$\begin{array}{c}\text { Total } \\
\text { Flow Rate } \\
(\mathrm{gpm}) \\
\end{array}$} & \multirow{2}{*}{$\begin{array}{c}\text { Approximate } \\
\text { Travel Speed } \\
\text { (ft/min) } \\
\end{array}$} & \multirow{2}{*}{$\begin{array}{c}\text { Air } \\
\text { Temp } \\
\left({ }^{0} \mathbf{F}\right) \\
\end{array}$} & \multirow{2}{*}{$\begin{array}{c}\text { Relative } \\
\text { Humidity } \\
(\%) \\
\end{array}$} & \multirow{2}{*}{$\begin{array}{l}\text { Wind } \\
\text { Speed } \\
(\mathrm{mph}) \\
\end{array}$} & \multirow{2}{*}{$\begin{array}{l}\text { Wind } \\
\text { Direction } \\
\text { (from) }\end{array}$} & \multirow[b]{2}{*}{$\begin{array}{l}\text { Spray Arm } \\
\text { Orientation }\end{array}$} \\
\hline & & $\begin{array}{c}\text { Outer End } \\
\text { of Arm }\end{array}$ & $\begin{array}{l}\text { Middle } \\
\text { of Arm }\end{array}$ & $\begin{array}{c}\text { Inner End } \\
\text { of Arm }\end{array}$ & & & & & & & \\
\hline 062 & 75 & $\# 12$ & $\# 12$ & $\# 12$ & 36 & 1.1 & $68-70$ & $65-68$ & $4-6$ & $\mathrm{NE}$ & NE-SW \\
\hline 063 & 55 & \#12 & $\# 12$ & \#12 & 30.5 & 1 & $70-74$ & 70 & $0-3$ & NE & NE-SW \\
\hline 064 & 75 & $\# 8$ & \#8 & \#8 & 21.5 & 1.1 & 74 & 70 & $0-5$ & $\mathrm{NE}$ & NE-SW \\
\hline 065 & 55 & $\# 12$ & $\# 12$ & $\# 8$ & 26.5 & 1 & 77 & 63 & $5-8$ & NNE & NE-SW \\
\hline 066 & 55 & \#12 & $\# 10$ & $\# 8$ & 25 & 0.7 & $74-78$ & 47 & $8-18$ & $\mathrm{~N}$ & E-W \\
\hline 067 & 73 & \#12 & $\# 10$ & $\# 8$ & 30 & 0.7 & $76-78$ & 59 & $7-16$ & $\mathrm{~N}$ & E-W \\
\hline 068 & 75 & \#12 & $\# 8$ & $\# 8$ & 27.5 & 0.7 & $63-65$ & 85 & $4-6$ & $\mathrm{E}$ & N-S \\
\hline 069 & 55 & \#12 & $\# 8$ & \#8 & 22.5 & 0.7 & $68-70$ & 70 & $0-3$ & $\mathrm{E}$ & N-S \\
\hline 070 & 55 & \#12 & \#8 & $\# 8$ & 23 & 1 & 92 & 48 & $0-5$ & W & $\mathrm{N}-\mathrm{S}$ \\
\hline
\end{tabular}

* Senninger Irrigation Products Super Spray ${ }^{\mathrm{TM}}$ spray heads and nozzles 
Table 2a

Results of Village Sprinkler Experiments - Purge-and-Trap Carbon Tetrachloride Analyses, $\mu \mathrm{g} / \mathrm{L}$

\begin{tabular}{|c|c|c|c|c|c|c|c|c|c|c|c|c|c|c|c|}
\hline \multirow[b]{2}{*}{ Run No. } & \multicolumn{13}{|c|}{ Rain Gauges } & \multicolumn{2}{|c|}{ Hydrant Samples } \\
\hline & $\mathbf{A}$ & B & $\mathbf{C}$ & D & $\mathbf{E}$ & $\mathbf{F}$ & $\mathbf{G}$ & $\mathbf{H}$ & I & $\mathbf{J}$ & $\mathbf{K}$ & $\mathbf{L}$ & $\mathbf{M}$ & Start & End \\
\hline 062 & na & na & 4.4 & 4.1 & 4.9 & 2.7 & 3.3 & 2.4 & na & na & --- & --- & --- & not smpld & 97 \\
\hline 063 & --- & na & 3.6 & 3.8 & 5.2 & 4.5 & 4.1 & 3.8 & 3.1 & na & --- & --- & --- & 117 & 111 \\
\hline 064 & --- & na & na & na & 1.0 & 0.8 & 0.9 & na & na & na & --- & --- & --- & 95 & 96 \\
\hline 065 & --- & --- & na & na & 4.7 & 3.7 & 3.4 & 1.6 & 3.3 & not smpld & na & na & na & 215 & 116 \\
\hline 066 & na & 2.8 & 2.2 & 2.9 & 1.9 & 3.7 & 1.5 & 1.3 & na & na & --- & --- & $3.8^{*}$ & 278 & 222 \\
\hline 067 & na & $<1$ & $<1$ & 1.3 & 1.4 & 2.0 & 1.0 & $<1$ & na & na & --- & --- & $2.5^{*}$ & 173 & 161 \\
\hline 068 & na & --- & 2.3 & 1.6 & 2.9 & 3.5 & 2.8 & 1.6 & 1.7 & na & na & na & $2.8^{*}$ & 156 & 155 \\
\hline 069 & --- & na & $2.8 \mathrm{~s}$ & 1.6 & 2.1 & 2.9 & 3.4 & 2.1 & 2.1 & 2.1 & na & --- & $3.3^{*}$ & 153 & 153 \\
\hline
\end{tabular}

Rain gauges spaced at $5 \mathrm{ft}$ intervals, perpe $<1$ icular to path of sprinkler travel

| Vertical bar $\mathrm{i}<1$ icates location of sprinkler; $15 \mathrm{ft}$ spacing between these two adjacent rain gauges.

na - No analysis due to insufficient sample volume

--- No spray recovered in rain gauge

* Rain gauge mounted on base of traveling sprinkler.

s - spike recoveries outside control limits 
Table 2b

Results of Village Sprinkler Experiments - Headspace Carbon Tetrachloride Analyses, $\mu \mathrm{g} / \mathrm{L}$

\begin{tabular}{|c|c|c|c|c|c|c|c|c|c|c|c|c|c|}
\hline \multirow[b]{2}{*}{ Run No. } & \multicolumn{13}{|c|}{ Rain Gauges } \\
\hline & A & B & $\mathrm{C}$ & D & $\mathbf{E}$ & $\mathbf{F}$ & $\mathbf{G}$ & $\mathbf{H}$ & I & $\mathbf{J}$ & $\mathbf{K}$ & $\mathbf{L}$ & $\mathbf{M}$ \\
\hline 062 & na & 2.7 & 3.6 & 3.5 & 3.8 & 2.0 & 2.9 & 2.6 & 2.8 & 0.8 & --- & --- & --- \\
\hline 063 & --- & 1.9 & 3.7 & 3.4 & 4.6 & | 4.4 & 3.8 & 3.0 & 2.6 & 3.1 & --- & --- & --- \\
\hline 064 & --- & 0.1 & 0.6 & 1.5 & 1.2 & | 0.8 & 0.9 & 0.7 & 0.4 & 1.0 & --- & --- & --- \\
\hline 065 & --- & --- & 1.7 & 2.3 & 3.9 & | 3.9 & 3.2 & 1.2 & 2.6 & 2.0 & 1.7 & 0.3 & na \\
\hline 066 & --- & 2.0 & 1.5 & $2.1 / 2.0$ & 1.5 & $2.6 / 2.7$ | & 1.0 & 0.9 & 1.5 & 1.3 & --- & --- & $2.5 / 3.2^{*}$ \\
\hline 067 & 1.2 & 0.8 & $0.7 / 0.7$ & 1.1 & 0.9 & $1.8 / 1.6$ | & $0.8 / 0.7$ & 0.6 & 0.7 & 0.7 & --- & --- & $2.0^{*}$ \\
\hline 068 & --- & $2.9 / 2.8$ & 2.0 & 1.4 & 2.0 & $2.7 / 2.7$ | & 2.2 & $1.2 / 1.4$ & 1.5 & $1.5 / 1.8$ & 0.6 & --- & $2.5^{*}$ \\
\hline 069 & --- & $1.3 / 1.6$ & 2.6 & 1.4 & $2.0 / 1.7$ & 2.2 & $2.5 / 2.5$ & 1.8 & 1.6 & 1.6 & 1.6 & --- & $2.3 / 2.2^{*}$ \\
\hline
\end{tabular}

Rain gauges spaced at $5 \mathrm{ft}$ intervals, perpendicular to path of sprinkler travel

Vertical bar indicates location of sprinkler; $15 \mathrm{ft}$ spacing between these two adjacent rain gauges.

na - No analysis due to insufficient sample volume

--- No spray recovered in rain gauge

* Rain gauge mounted on base of traveling sprinkler. 


\section{Table 3}

\section{Results of Village Sprinkler Experiments - Application Depth, Inches of Water}

\begin{tabular}{|c|c|c|c|c|c|c|c|c|c|c|c|c|c|}
\hline \multirow[b]{2}{*}{ Run No. } & \multicolumn{13}{|c|}{ Rain Gauges } \\
\hline & $\mathbf{A}$ & B & $\mathbf{C}$ & D & $\mathbf{E}$ & $\mathbf{F}$ & $\mathbf{G}$ & $\mathbf{H}$ & $\mathbf{I}$ & $\mathbf{J}$ & $\mathbf{K}$ & $\mathbf{L}$ & $\mathbf{M}$ \\
\hline 062 & 0.02 & 0.18 & 0.38 & 0.64 & 1.35 & 1.25 & 0.80 & 0.46 & 0.18 & 0.01 & --- & --- & --- \\
\hline 063 & --- & 0.06 & 0.33 & 0.63 & 1.10 & 1.40 & 1.15 & 0.70 & 0.40 & 0.09 & --- & --- & --- \\
\hline 064 & --- & $<0.01$ & 0.14 & 0.26 & 0.48 & 0.70 & 0.50 & 0.24 & 0.13 & 0.02 & --- & --- & --- \\
\hline 065 & --- & --- & 0.06 & 0.28 & 0.50 & 0.98 & 0.84 & 0.76 & 0.60 & 0.43 & 0.16 & 0.01 & $<0.01$ \\
\hline 066 & 0.01 & 0.30 & 0.62 & 0.90 & 1.25 & 1.30 & 0.64 & 0.44 & 0.22 & 0.03 & --- & --- & $0.90 *$ \\
\hline 067 & 0.08 & 0.44 & 0.70 & 1.10 & 1.35 & 1.55 & 0.84 & 0.58 & 0.26 & 0.04 & --- & --- & $1.15^{*}$ \\
\hline 068 & $<0.01$ & 0.26 & 0.61 & 0.74 & 1.50 & 1.70 & 1.05 & 0.90 & 0.70 & 0.28 & 0.05 & 0.02 & $2.50 *$ \\
\hline 069 & & 0.06 & 0.40 & 0.62 & 0.94 & 1.40 & 1.20 & 0.93 & 0.64 & 0.32 & 0.03 & --- & $2.00 *$ \\
\hline 070 & 0.01 & 0.20 & 0.32 & 0.44 & 0.74 & 1.05 & 0.73 & 0.40 & 0.38 & 0.12 & ng & ng & ng \\
\hline
\end{tabular}

Rain gauges spaced at $5 \mathrm{ft}$ intervals, perpendicular to path of sprinkler travel

Vertical bar indicates location of sprinkler; $15 \mathrm{ft}$ spacing between these two adjacent rain gauges.

* Rain gauge mounted on base of traveling sprinkler.

ng - No gauge 
Table 4

\begin{tabular}{cccc} 
& $\begin{array}{c}\text { Maximum } \\
\text { Application } \\
\text { inches }\end{array}$ & \multicolumn{2}{c}{ Width of Spray Pattern (ft) } \\
\cline { 3 - 4 } 062 & 1.35 & 32 & 49 \\
$\begin{array}{c}\text { Application } \\
\mathbf{> 0 . 5} \text { inch }\end{array}$ & $\begin{array}{c}\text { Application } \\
\mathbf{> 0 . 1} \text { inch }\end{array}$ \\
063 & 1.4 & 36 & 48 \\
064 & 0.7 & 19 & 42 \\
065 & 0.98 & 33 & 50 \\
066 & 1.3 & 35 & 51 \\
067 & 1.55 & 41 & 53 \\
068 & 1.7 & 44 & 56 \\
069 & 1.4 & 41 & 52 \\
070 & 1.05 & 28 & 50 \\
\hline \hline
\end{tabular}

